\title{
Effects of Calcium and Calcitonin on Circulating Levels of Glucagon and Glucose in Diabetes Mellitus
}

\author{
A. Starke, E. Keck, M. Berger, and H. Zimmermann \\ Department of Medicine E, University of Düsseldorf, Düsseldorf, Federal Republic of Germany
}

Summary. The effects of $\mathrm{Ca}^{2+}$ and calcitonin infusions on circulating glucagon, glucose, C-peptide, $\mathrm{Ca}^{2+}$, and calcitonin were investigated in hyperglucagonaemic insulin-dependent diabetics. In 14 insulin-deprived diabetics and 12 healthy volunteers $2 \mathrm{~h}$ infusions of saline $(0.154 \mathrm{~mol} / \mathrm{l}), \mathrm{Ca}^{2+}(0.375$ $\mathrm{mmol} / \mathrm{kg}$ body weight), and calcitonin $(4.5 \mathrm{IU} / \mathrm{kg}$ body weight) were performed. There were no significant changes during saline infusion. In the diabetics, $\mathrm{Ca}^{2+}$ infusions induced a rise of plasma $\mathrm{Ca}^{2+}$ up to $3.2 \pm 0.1 \mathrm{mmol} / \mathrm{l}$ and a fall of circulating glucagon $(-26.4 \pm 5.7 \% ; \mathrm{p}<0.001)$ and glucose $(-23.3$ $\pm 3.6 \% ; \mathrm{p}<0.05)$. Plasma calcitonin rose to twice basal values $(p<0.025)$. During calcitonin infusions plasma $\mathrm{Ca}^{2+}$ decreased slightly to $2.1 \pm 0.2 \mathrm{mmol} / \mathrm{l}$; a fall was found in both glucose $(-24.4 \pm 4.0 \%$; $\mathrm{p}<0.05)$ and circulating glucagon $(-22.5 \pm 4.3 \%$; $\mathrm{p}<0.001$ ). Two groups of 6 healthy volunteers were subjected to saline and $\mathrm{Ca}^{2+}$, or to $\mathrm{Ca}^{2+}$ and calcitonin infusions. Both $\mathrm{Ca}^{2+}$ and calcitonin infusions induced a fall of serum insulin $(-30.1 \pm 6.6 \%$; $p<$ 0.05 ). Calcitonin depressed circulating glucagon by $-18.6 \pm 4.4 \%(\mathrm{p}<0.025)$, whereas during $\mathrm{Ca}^{2+}$ infusions glucagon decreased only by $-6.5 \pm 1.9 \%$ $(p>0.1)$. We conclude from our results that an increase of circulating calcitonin induced by $\mathrm{Ca}^{2+}$ infusions or by exogenous calcitonin administration appears to depress elevated circulating glucagon and glucose in insulin-dependent diabetics.

Key words: Insulin-dependent diabetes mellitus, $\mathrm{Ca}^{2+}$, glucagon release, calcitonin release, insulin release.

Recently we have demonstrated in healthy subjects that $\mathrm{Ca}^{2+}$ infusions lower the plasma glucagon levels stimulated by arginine or insulin-induced hypoglycaemia. $\mathrm{Ca}^{2+}$ was, however, ineffective in altering basal circulating glucagon levels to a significant extent [1]. In insulin-dependent diabetics the basal levels of circulating glucagon are often found to be elevated $[2,3,4,5]$. It is known that a stimulated calcitonin release from the thyroid gland is found during $\mathrm{Ca}^{2+}$ administration [6]. In the present study we have therefore investigated the effects of $\mathrm{Ca}^{2+}$ and calcitonin infusions on circulating glucagon levels and elevated blood glucose concentrations in insulindependent diabetics following a 12 hour period of insulin-withdrawal.

\section{Materials and Methods}

Fourteen patients with insulin-dependent diabetes mellitus (clinical data and mean baseline values on the day of experiment are shown in Table 1) who had been treated with two daily injections of intermediate long-acting insulin and one morning dose of regular insulin and a weight-maintaining diet in our metabolic ward for about ten days were chosen for the study. The patients were free of coronary heart disease, had no signs of cardiac failure, and were shown to have a normal creatinine clearance as well as normal basal plasma $\mathrm{Ca}^{2+}$. In addition, 12 normal subjects, matched for age, sex, and body weight were examined. They all gave their informed consent to participate in the study which was carried out according to the principles of the declaration of Helsinki.

Tests were performed after an overnight fast in 14 insulindependent diabetics who had received their last usual insulin injection $24 \mathrm{~h}$ before the tests. On the morning of investigation, two Teflon catheters were inserted into contralateral antecubital veins; one was kept patent by an infusion of $0.154 \mathrm{~mol} / \mathrm{l}$ saline, the other was used to infuse over 2 hours $0.375 \mathrm{mmol} / \mathrm{kg}$ body weight of $\mathrm{Ca}^{2+}$ as a $200 \mathrm{~g} / 1$ solution of calcium gluconate $(\mathrm{n}=7)$ or $4.5 \mathrm{IU} /$ $\mathrm{kg}$ body weight of salmon calcitonin dissolved in $30 \mathrm{ml}$ of saline $(\mathrm{n}=4)$ using an infusion pump (Braun-Melsungen, West Germany). The total infused volume during the experimental period of $300 \mathrm{~min}$ did not exceed $250 \mathrm{ml}$. An equivalent volume of $250 \mathrm{ml}$ of $0.154 \mathrm{~mol} / \mathrm{l}$ saline was infused in 5 patients as control. Blood samples were drawn at indicated time intervals up to $300 \mathrm{~min}$ after the onset of the infusions and immediately discharged into refrigerated tubes containing $1000 \mathrm{U}$ of Trasylol and $1.2 \mathrm{mg}$ of $\mathrm{Na}_{2}$ EDTA/ml of blood for glucagon and calcitonin immunoassays.

Six healthy volunteers were subjected to saline and $\mathrm{Ca}^{2+}$ infusions on two different days under the same conditions as the dia- 
Table 1. Clinical data and baseline values of insulin-dependent diabetic and healthy control subjects on the day of saline (NaCl), $\mathrm{Ca}^{2+}$, or calcitonin infusion. Mean \pm SD and the range of mean daily insulin dosage, plasma C-peptide, and plasma glucagon (diabetics) are given. ${ }^{a}=$ statistically significant differences from healthy controls $(\mathrm{p}<0.05)$ in the corresponding infusion-test

\begin{tabular}{|c|c|c|c|c|c|c|c|c|c|c|c|}
\hline & \multirow[t]{2}{*}{$\mathbf{n}$} & \multirow{2}{*}{$\begin{array}{l}\text { Sex } \\
(\mathrm{m} / \mathrm{f})\end{array}$} & \multirow{2}{*}{$\begin{array}{l}\text { Age } \\
\text { (years) }\end{array}$} & \multirow{2}{*}{$\begin{array}{l}\text { Age of } \\
\text { onset of } \\
\text { diabetes } \\
\text { (years) }\end{array}$} & \multirow{2}{*}{$\begin{array}{l}\text { Mean } \\
\text { daily } \\
\text { insulin } \\
\text { dosage } \\
\text { (range) }\end{array}$} & \multirow{2}{*}{$\begin{array}{l}\text { Body } \\
\text { weight } \\
\text { (Broca- } \\
\text { Index) }\end{array}$} & \multicolumn{5}{|c|}{ Baseline values on the day of experiment } \\
\hline & & & & & & & $\begin{array}{l}\text { Blood } \\
\text { glucose } \\
(\mathrm{mmol} / \mathrm{l})\end{array}$ & $\begin{array}{l}\text { Serum } \\
\text { insulin } \\
(\mathrm{mU} / \mathrm{l})\end{array}$ & $\begin{array}{l}\text { Plasma } \\
\text { C-peptide } \\
(\mu \mathrm{g} / \mathrm{l}) \\
\text { (range) }\end{array}$ & $\begin{array}{l}\text { Plasma } \\
\text { glucagon } \\
\text { (ng/1) } \\
\text { (range) }\end{array}$ & $\begin{array}{l}\text { Plasma } \\
\text { calcium } \\
\text { (mmol/l) }\end{array}$ \\
\hline $\begin{array}{l}\text { Diabetics } \\
(\mathrm{NaCl})\end{array}$ & 5 & $\begin{array}{l}4 \mathrm{~m} \\
\text { 1f }\end{array}$ & $29 \pm 9$ & $19 \pm 10$ & $\begin{array}{c}48 \mathrm{IU} \\
(28-76)\end{array}$ & $0.94 \pm 0.11$ & $11.9 \pm 2.2^{\mathrm{a}}$ & - & $\begin{array}{l}0.45 \pm 0.22 \\
(0.20-0.78)\end{array}$ & $\begin{array}{l}154 \pm 123^{a} \\
(38-295)\end{array}$ & $2.0 \pm 0.2$ \\
\hline $\begin{array}{l}\text { Diabetics } \\
\left(\mathrm{Ca}^{2+}\right)\end{array}$ & 7 & $\begin{array}{l}6 \mathrm{~m} \\
\text { 1f }\end{array}$ & $23 \pm 6$ & $18 \pm 6$ & $\begin{array}{c}52 \mathrm{IU} \\
(36-82)\end{array}$ & $0.93 \pm 0.12$ & $13.1 \pm 3.2^{\mathrm{a}}$ & - & $\begin{array}{l}0.52 \pm 0.21 \\
(0.0-0.78)\end{array}$ & $\begin{array}{r}87 \pm 31^{\mathbf{a}} \\
(52-148)\end{array}$ & $2.2 \pm 0.2$ \\
\hline $\begin{array}{l}\text { Diabetics } \\
\text { (calcitonin) }\end{array}$ & 4 & $\begin{array}{l}3 \mathrm{~m} \\
1 \mathrm{f}\end{array}$ & $25 \pm 5$ & $20 \pm 7$ & $\begin{array}{l}56 \mathrm{IU} \\
(40-100)\end{array}$ & $0.93 \pm 0.14$ & $17.1 \pm 3.8^{\mathrm{a}}$ & - & $\begin{array}{l}0.35 \pm 0.19 \\
(0.15-0.56)\end{array}$ & $\begin{array}{l}128 \pm 9^{a} \\
(116-135)\end{array}$ & $2.4 \pm 0.4$ \\
\hline $\begin{array}{l}\text { Controls } \\
(\mathrm{NaCl})\end{array}$ & 6 & $6 \mathrm{~m}$ & $24 \pm 3$ & - & - & $0.95 \pm 0.10$ & $5.0 \pm 1.2$ & $11.3 \pm 5.3$ & - & $54 \pm 28$ & $2.4 \pm 0.4$ \\
\hline Controls & 6 & $6 \mathrm{~m}$ & $24 \pm 3$ & - & - & $0.95 \pm 0.10$ & $4.7 \pm 0.5$ & $8.8 \pm 5.3$ & - & $61 \pm 29$ & $2.3 \pm 0.2$ \\
\hline$\left(\mathrm{Ca}^{2+}\right)$ & 6 & $6 \mathrm{~m}$ & $32 \pm 6$ & - & - & $0.93 \pm 0.13$ & $5.4 \pm 0.6$ & $5.4 \pm 1.1$ & - & $77 \pm 21$ & $2.4 \pm 0.1$ \\
\hline $\begin{array}{l}\text { Controls } \\
\text { (calcitonin) }\end{array}$ & 6 & $6 \mathrm{~m}$ & $32 \pm 6$ & - & - & $0.93 \pm 0.13$ & $5.2 \pm 0.5$ & $6.9 \pm 2.5$ & - & $85 \pm 22$ & $2.4 \pm 0.2$ \\
\hline
\end{tabular}

Table 2. Effect of $\mathrm{Ca}^{2+}$ infusions $(0.375 \mathrm{mmol} / \mathrm{kg})$ on circulating levels of $\mathrm{Ca}^{2+}$, calcitonin, glucagon, blood glucose, and C-peptide in insulin-dependent diabetics ( $\mathrm{n}=7$ ). Infusions were carried out between 0 and $120 \mathrm{~min}$; means \pm SEM are given. ${ }^{a}$ statistically significant differences from baseline values $(p<0.05$; paired Student t-test)

\begin{tabular}{rlllll}
\hline $\begin{array}{l}\text { Time } \\
\text { min }\end{array}$ & $\begin{array}{l}\text { Calcium } \\
\mathrm{mmol} / \mathrm{l}\end{array}$ & $\begin{array}{l}\text { Calcitonin } \\
\mathrm{ng} / \mathrm{l}\end{array}$ & $\begin{array}{l}\text { Glucagon } \\
\mathrm{ng} / \mathrm{l}\end{array}$ & $\begin{array}{l}\text { Glucose } \\
\mathrm{mmol} / \mathrm{l}\end{array}$ & $\begin{array}{l}\text { C-peptide } \\
\mu \mathrm{g} / \mathrm{l}\end{array}$ \\
\hline 0 & $2.2 \pm 0.1$ & $475 \pm 85$ & $87 \pm 12$ & $13.1 \pm 1.2$ & $0.52 \pm 0.08$ \\
30 & $2.5 \pm 0.1$ & $510 \pm 95$ & $81 \pm 12$ & $12.6 \pm 1.2$ & $0.46 \pm 0.09$ \\
60 & $2.9 \pm 0.2^{\mathrm{a}}$ & $710 \pm 120^{\mathrm{a}}$ & $78 \pm 13^{\mathrm{a}}$ & $12.1 \pm 1.0$ & $0.50 \pm 0.09$ \\
90 & $3.0 \pm 0.1^{\mathrm{a}}$ & $850 \pm 115^{\mathrm{a}}$ & $76 \pm 12^{\mathrm{a}}$ & $11.7 \pm 1.0$ & $0.48 \pm 0.12$ \\
120 & $3.2 \pm 0.1^{\mathrm{a}}$ & $670 \pm 120^{\mathrm{a}}$ & $67 \pm 13^{\mathrm{a}}$ & $11.1 \pm 1.0^{\mathrm{a}}$ & $0.47 \pm 0.11$ \\
180 & $2.9 \pm 0.1^{\mathrm{a}}$ & $510 \pm 110$ & $77 \pm 12^{\mathrm{a}}$ & $10.8 \pm 1.1^{\mathrm{a}}$ & $0.42 \pm 0.08$ \\
240 & $2.9 \pm 0.1^{\mathrm{a}}$ & $460 \pm 85$ & $80 \pm 13$ & $10.7 \pm 1.3^{\mathrm{a}}$ & $0.41 \pm 0.09$ \\
300 & $2.6 \pm 0.1$ & $395 \pm 70$ & $87 \pm 11$ & $10.1 \pm 1.3^{\mathrm{a}}$ & $0.37 \pm 0.08$ \\
\hline
\end{tabular}

betic subjects. Six other volunteers received an infusion of $0.375 \mathrm{mmol} / \mathrm{kg}$ body weight of $\mathrm{Ca}^{2+}$ as calcium gluconate and an infusion of $4.5 \mathrm{IU} / \mathrm{kg}$ body weight of porcine calcitonin within $2 \mathrm{~h}$ on two different days. Blood samples were drawn before and $120 \mathrm{~min}$ after the onset of infusions.

Plasma $\mathrm{Ca}^{2+}$ was measured by atomic absorption; blood glucose enzymatically; serum insulin, plasma C-peptide, plasma glucagon [7, 8], and plasma calcitonin [9] were measured by immunoassay. Plasma glucagon was assayed using the antibody $30 \mathrm{~K}$ (pool 4, lot 3, 1978), kindly provided by Dr. R. Unger, Dallas, Texas. The charcoal dextran separation technique was performed. The limit of sensitivity of the glucagon immunoassay was $20 \mathrm{ng} / \mathrm{l}$ at the $97.5 \%$ confidence limit; the interassay coefficient of variation was $20 \%$ at a concentration of $40 \mathrm{ng} / 1$ and $12.5 \%$ at $115 \mathrm{ng} / \mathrm{l}$. Calcitonin was assayed using a commercially available kit system (RIA-mat calcitonin, Byk-Mallinckrodt, West Germany). The antiserum in this system was raised in a goat against synthetic human calcitonin according to Dietrich et al. [9]. The doubleantibody separation technique was used in the presence of polyethylene glycol. Standards were made up in calcitonin-free human serum prepared by florisil extraction. Salmon and porcine calcitonin are not detectable in this assay. The sensitivity of the calcitonin immunoassay was $50 \mathrm{ng} / \mathrm{l}$; the interassay coefficient of variation was $10 \%$ at a concentration of $500 \mathrm{ng} / \mathrm{l}$.

Data in the text, tables and figure are given as mean \pm SEM unless otherwise indicated (Table 1: mean \pm SD). Standard statistical methods have been employed using Student's paired and unpaired t-tests.

\section{Results}

Basal circulating plasma glucagon levels were significantly higher in the diabetic patients (112 \pm $16 \mathrm{ng} / \mathrm{l}$ in the entire group of 14 diabetics; range $38-295 \mathrm{ng} / \mathrm{l})$ than in normal volunteers $(69 \pm 5 \mathrm{ng} / \mathrm{l}$; range $44-115 \mathrm{ng} / \mathrm{l} ; \mathrm{n}=12 ; \mathrm{p}<0.025)$.

\section{Saline Infusions}

In normal subjects $(\mathrm{n}=6)$ saline infusions had no significant effect on any of the hormones or metabolites measured. Plasma glucagon remained constant at $50 \pm 9 \mathrm{ng} / \mathrm{l} ;$ serum insulin at $9.6 \pm 1.8 \mathrm{mU} / 1 ; \mathrm{Ca}^{2+}$ at $2.3 \pm 0.1 \mathrm{mmol} / 1$. In the diabetic patients, blood glucose was $11.9 \pm 1.0 \mathrm{mmol} / 1$ in the basal state and $13.3 \pm 1.7 \mathrm{mmol} / \mathrm{l}$ at the end of the experimental period after $300 \mathrm{~min}$, whereas plasma $\mathrm{Ca}^{2+}$, circulating glucagon, and C-peptide remained unchanged $(2.0 \pm 0.06 \mathrm{mmol} / \mathrm{l} ; 146 \pm 44 \mathrm{ng} / \mathrm{l} ; 0.51 \pm 0.16$ $\mu \mathrm{g} / \mathrm{l})$. 


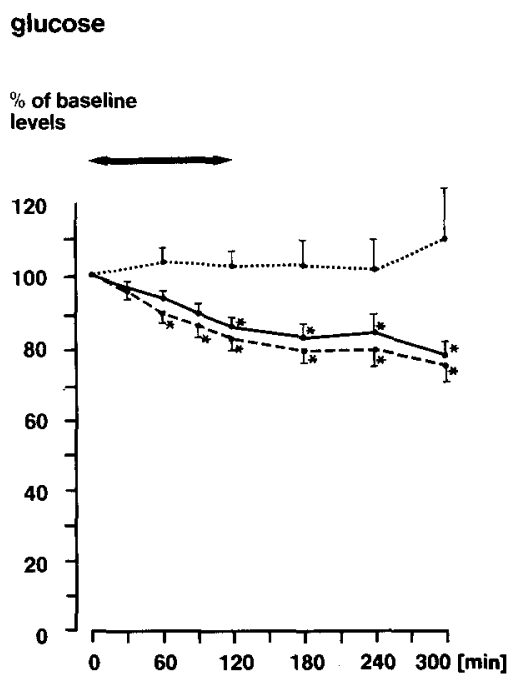

glucagon
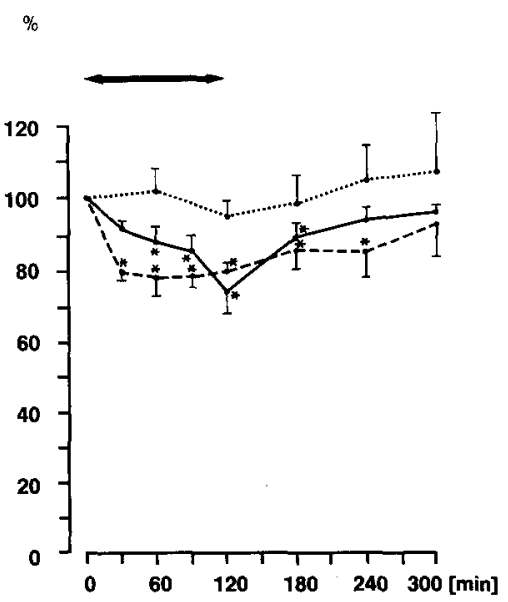

calcium

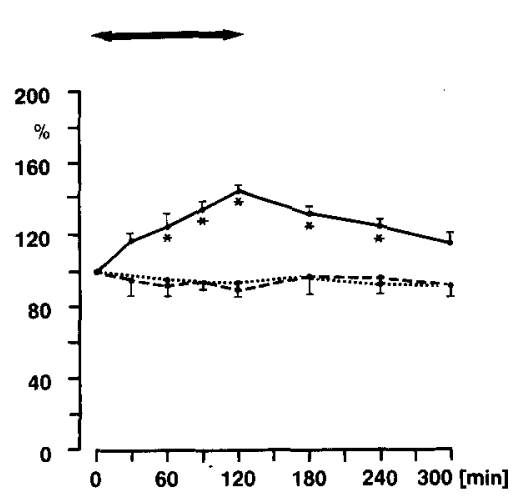

calcitonin

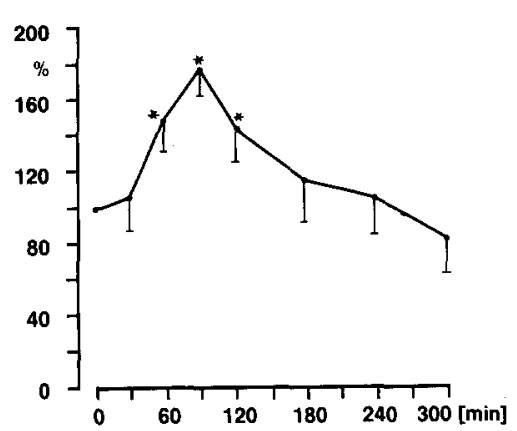

Fig. 1. Effects of saline ... $(n=5)$, $\mathrm{Ca}^{2+} \ldots(\mathrm{n}=7)$, and calcitonin - $(n=4)$ infusions on glucose, glucagon, calcium, and calcitonin levels in insulin-dependent diabetics. $\leftrightarrow$ indicates the $2 \mathrm{~h}$ infusion period of $0.375 \mathrm{mmol} \mathrm{Ca}^{2+} / \mathrm{kg}$ or $4.5 \mathrm{IU}$ calcitonin $/ \mathrm{kg}$. Values are given in \% of mean baseline levels \pm SEM. The absolute mean baseline values are shown in Tables 1,2 , and $4 . *$ indicates statistically significant differences $(\mathrm{p}<0.05)$ for glucose and glucagon: $\mathrm{Ca}^{2+}$, calcitonin vs. saline infusions; calcium: $\mathrm{Ca}^{2+}$ vs. saline, calcitonin infusions; calcitonin: vs. mean baseline values

\section{$C a^{2+}$ Infusions}

During $\mathrm{Ca}^{2+}$ infusions plasma $\mathrm{Ca}^{2+}$ levels rose from $2.4 \pm 0.05 \mathrm{mmol} / 1$ to $3.6 \pm 0.1 \mathrm{mmol} / 1$ in normal subjects and from $2.2 \pm 0.1 \mathrm{mmol} / 1$ to $3.2 \pm$ $0.1 \mathrm{mmol} / 1$ in the diabetic patients $(\mathrm{p}<0.001)$. The administration of $\mathrm{Ca}^{2+}$ induced in normal subjects $(\mathrm{n}=6)$ a fall in circulating insulin (from $8.8 \pm 2.2$ to $3.9 \pm 0.5 \mathrm{mU} / 1 ; \mathrm{p}<0.05)$ and a questionable decrease in plasma glucagon (from $61 \pm 12$ to $49 \pm$ $11 \mathrm{ng} / \mathrm{l} ; \mathrm{p}>0.1$ ) at the end of the $2 \mathrm{~h} \mathrm{Ca}^{2+}$ infusions. Blood glucose levels remained unchanged. In contrast, in insulin-dependent diabetics, $\mathrm{Ca}^{2+}$ infusions induced a significant linear fall of blood glucose $(-23.3 \pm 3.6 \%$ of mean baseline values; $p<0.05)$ even after cessation of $\mathrm{Ca}^{2+}$ administration. Plasma calcitonin rose to twice basal values $90 \mathrm{~min}$ after the onset of $\mathrm{Ca}^{2+}$ infusions $(\mathrm{p}<0.025$ ). Plasma glucagon fell significantly by $-26.4 \pm 5.7 \%(p<0.001)$
$30 \mathrm{~min}$ after calcitonin peak values. A low basal plasma C-peptide appeared to decrease further throughout the experimental period. Five hours after the onset of $\mathrm{Ca}^{2+}$ infusions, the calcitonin and glucagon levels had returned of the basal range (Table 2 and Fig. 1).

\section{Calcitonin Infusions}

During calcitonin infusions plasma $\mathrm{Ca}^{2+}$ showed no significant change $(2.4 \pm 0.2$ to $2.1 \pm 0.1 \mathrm{mmol} / \mathrm{l})$, remaining within the normal range in normal and diabetic subjects. A $2 \mathrm{~h}$ infusion of calcitonin in six normal subjects caused a fall in serum insulin (from $6.9 \pm 1.0$ to $4.9 \pm 1.5 \mathrm{mU} / \mathrm{l} ; \mathrm{p}<0.01$ ) and plasma glucagon (from $85 \pm 9$ to $69 \pm 9 \mathrm{ng} / \mathrm{l} ; \mathrm{p}<0.025$ ) whereas blood glucose increased from $5.2 \pm 0.2$ to $7.0 \pm 0.3 \mathrm{mmol} / 1(\mathrm{p}<0.001)$. In this group, control studies with $\mathrm{Ca}^{2+}$ infusions caused a fall in serum 
Table 3. Effect of calcitonin $(4.5 \mathrm{IU} / \mathrm{kg})$ and $\mathrm{Ca}^{2+}$ infusions $(0.375 \mathrm{mmol} / \mathrm{kg})$ on circulating levels of glucagon, insulin, glucose, and $\mathrm{Ca}^{2+}$ in 6 normal subjects. Means \pm SEM are given; symbols as in Table 2. Infusions were carried out between 0 and $2 \mathrm{~h}$. ${ }^{a}=$ statistically significant differences from basal values $(p<0.05)$

\begin{tabular}{llllll}
\hline & & $\begin{array}{l}\text { Glucagon } \\
\mathrm{ng} / \mathrm{l}\end{array}$ & $\begin{array}{l}\text { Insulin } \\
\mathrm{mU} / 1\end{array}$ & $\begin{array}{l}\text { Glucose } \\
\mathrm{mmol} / \mathrm{l}\end{array}$ & $\begin{array}{l}\text { Calcium } \\
\mathrm{mmol} / 1\end{array}$ \\
\hline Calcitonin & basal & $85 \pm 9$ & $6.9 \pm 1.0$ & $5.2 \pm 0.2$ & $2.4 \pm 0.2$ \\
infusion & $2 \mathrm{~h}$ & $69 \pm 9^{\mathrm{a}}$ & $4.9 \pm 1.5^{\mathrm{a}}$ & $7.0 \pm 0.3^{\mathrm{a}}$ & $2.1 \pm 0.1$ \\
Calcium & basal & $77 \pm 9$ & $5.4 \pm 0.5$ & $5.4 \pm 0.2$ & $2.4 \pm 0.1$ \\
infusion & $2 \mathrm{~h}$ & $73 \pm 9$ & $3.9 \pm 0.4^{\mathrm{a}}$ & $5.6 \pm 0.2$ & $3.6 \pm 0.1^{\mathrm{a}}$ \\
\hline
\end{tabular}

Table 4. Effect of calcitonin infusions $(4.5 \mathrm{IU} / \mathrm{kg})$ on circulating levels of $\mathrm{Ca}^{2+}$, glucagon, and glucose in insulin-dependent diabetics $(n=4)$. Means \pm SEM are given; symbols as in Table 2

\begin{tabular}{rlrl}
\hline $\begin{array}{l}\text { Time } \\
\min \end{array}$ & $\begin{array}{l}\text { Calcium } \\
\text { mmol/l }\end{array}$ & $\begin{array}{l}\text { Glucagon } \\
\text { pg/ml }\end{array}$ & $\begin{array}{l}\text { Glucose } \\
\text { mmol/l }\end{array}$ \\
\hline 0 & $2.4 \pm 0.2$ & $128 \pm 5$ & $17.1 \pm 1.9$ \\
30 & $2.2 \pm 0.2$ & $102 \pm 4^{\mathrm{a}}$ & $16.4 \pm 1.8$ \\
60 & $2.2 \pm 0.1$ & $99 \pm 4^{\mathrm{a}}$ & $15.1 \pm 1.5^{\mathrm{a}}$ \\
90 & $2.2 \pm 0.1$ & $100 \pm 5^{\mathrm{a}}$ & $14.5 \pm 1.4^{\mathrm{a}}$ \\
120 & $2.1 \pm 0.1$ & $102 \pm 4^{\mathrm{a}}$ & $14.0 \pm 1.6^{\mathrm{a}}$ \\
180 & $2.3 \pm 0.2$ & $111 \pm 6^{\mathrm{a}}$ & $13.2 \pm 1.6^{\mathrm{a}}$ \\
240 & $2.3 \pm 0.2$ & $109 \pm 9$ & $13.3 \pm 1.4^{\mathrm{a}}$ \\
300 & $2.2 \pm 0.2$ & $118 \pm 12$ & $12.6 \pm 1.2^{\mathrm{a}}$ \\
\hline
\end{tabular}

insulin from $5.4 \pm 0.5$ to $3.9 \pm 0.4 \mathrm{mU} / \mathrm{l}(\mathrm{p}<$ $0.025)$; plasma glucagon levels showed no significant change ( $77 \pm 9$ to $73 \pm 9 \mathrm{ng} / \mathrm{l}$ ), but this was significantly different when compared with the calcitonin infusions. Blood glucose levels remained unchanged. These data are summarized in Table 3 . In the diabetic patients, blood glucose levels decreased significantly during calcitonin infusions by $-24.4 \pm 4.0 \%$ $(\mathrm{p}<0.05)$; plasma glucagon fell significantly $30 \mathrm{~min}$ after the onset of calcitonin infusions by $-22.5 \pm$ $4.3 \%$ of the mean baseline values $(p<0.001)$ and remained at this level throughout the $2 \mathrm{~b}$ infusion of calcitonin. The effect of calcitonin infusions on blood glucose and plasma glucagon levels was similar to the effect of $\mathrm{Ca}^{2+}$ administration. The initial decrease of circulating glucagon was more pronounced during exogenous calcitonin infusions than during $\mathrm{Ca}^{2+}$ administration, however. Five hours after the onset of infusions plasma glucagon had returned to the basal values (Table 4 and Fig. 1).

\section{Discussion}

Since Unger and Orci re-emphasised the hypothesis of the bihormonal nature of the metabolic disturbances in diabetes mellitus [10], several attempts have been made to normalise hyperglycaemia in insulindependent diabetics by an inhibition of pancreatic glucagon secretion [11]. Thus, somatostatin [12, 13], somatostatin analogues [14] as well as anti-inflammatory drugs [15] have been shown to improve acutely metabolic disturbances in diabetic patients presumably due to a decrease in circulating glucagon levels.

In seven insulin-dependent diabetics $24 \mathrm{~h}$ after their last insulin injection a temporary hypercalcaemia associated with a substantial rise of plasma calcitonin induced a significant fall of plasma glucagon and blood glucose concentrations. The same effect on blood glucose and glucagon levels was found during calcitonin administration at normal plasma $\mathrm{Ca}^{2+}$; the initial decrease of circulating glucagon was more pronounced during calcitonin infusions. We were unable to determine the plasma concentrations of exogenous calcitonin because our calcitonin immunoassay was only sensitive to human calcitonin. However, although the amount of calcitonin administered in this study was of a magnitude to give rise to blood concentrations well above the physiological range on the basis of approximations of the pharmacokinetics [16], we found the effects on blood glucose and circulating glucagon within a similar range as during endogenous calcitonin stimulation due to hypercalcaemia. Our plasma glucagon levels determined with the antibody $30 \mathrm{~K}$ represent total glucagon immunoreactivity (IRG). Therefore we are unable to assess if pancreatic glucagon $\left(\mathrm{IRG}^{3500}\right)$ is altered during $\mathrm{Ca}^{2+}$ or calcitonin infusions.

Previously we have demonstrated in normal subjects that $\mathrm{Ca}^{2+}$ infusions, which induced a rise in plasma calcitonin levels, inhibited the arginine- and hypoglycaemia-induced stimulation of glucagon release [1]. In addition, even the low basal plasma glucagon levels in healthy subjects were significantly decreased during calcitonin infusions in this study.

It is known that calcitonin inhibits gastric and exocrine pancreatic secretion as well as the secretion of insulin $[17,18]$. Calcitonin reduces glucoseinduced insulin secretion [19] as well as argininestimulated insulin secretion [20] in normal man. No data on glucagon secretion were reported in these studies. Ohneda et al. [21] and Tamarit et al. [22] demonstrated a suppressive effect of $\mathrm{Ca}^{2+}$ administration on glucagon secretion in dogs in vivo but different antibodies were used for glucagon immunoassays in these studies. Although data concerning calcitonin levels during $\mathrm{Ca}^{2+}$ administration in these in vivo studies are not reported the results are in accordance with our findings in diabetics and normal man when extracellular $\mathrm{Ca}^{2+}$ levels were elevated. It is assumed that calcitonin exerts its inhibitory effect 
on hormone release via a stimulated $\mathrm{Ca}^{2+}$ efflux from the cells and intracellular movements of $\mathrm{Ca}^{2+}$, that is a decrease of cytosolic $\mathrm{Ca}^{2+}$ content and an enhancement of mitochondrial $\mathrm{Ca}^{2+}$ content $[17,23,24,25$, 26].

Effects of extracellular $\mathrm{Ca}^{2+}$ concentrations on glucagon release in vitro from the perfused isolated rat pancreas have been reported by Leclercq-Meyer et al. $[27,28]$. Omission of $\mathrm{Ca}^{2+}$ from the perfusion medium induced a significant enhancement of glucagon release whereas elevated extracellular $\mathrm{Ca}^{2+}$ concentrations of $4 \mathrm{mmol} / 1$ did not modify the glucagon release in the absence of calcitonin. On the other hand, in the perfused rat pancreas calcitonin failed to inhibit glucagon release during rising glucose concentrations [29].

The important role of $\mathrm{Ca}^{2+}$ in the stimulus-secretion coupling mechanisms of hormone release is generally accepted though the precise mechanisms concerning glucagon release are still not completely worked out: The presence of extracellular $\mathrm{Ca}^{2+}$ ions is required for an adaequate glucagon release [ 28 , $30]$ and high glucose concentrations fail to inhibit glucagon release in the absence of $\mathrm{Ca}^{2+}$ in the perfusion mediums $[28,31]$. Inhibited $\mathrm{Ca}^{2+}$ uptake of the $\alpha$-cells by verapamil is associated with decreased glucagon release during certain stimulatory conditions in vitro. Thus, in addition to the presence of extracellular $\mathrm{Ca}^{2+}$ ions per se, the $\alpha$-cell requires the integrity of inward $\mathrm{Ca}^{2+}$ transport $[32,33]$.

In normal volunteers, calcitonin infusions induced a significant decrease of circulating glucagon levels whereas $\mathrm{Ca}^{2+}$ administration did not depress normal basal glucagon levels significantly. Because of a substantial decrease of serum insulin during both $\mathrm{Ca}^{2+}$ and calcitonin infusions, the effects of the glucagon depression on blood glucose levels were masked. In insulin-deprived diabetics, we have demonstrated a progressive fall of blood glucose during $\mathrm{Ca}^{2+}$ administration, perhaps as a consequence of a decrease of the elevated circulating glucagon levels. During $\mathrm{Ca}^{2+}$ infusions, however, there was an increase of both plasma $\mathrm{Ca}^{2+}$ and plasma calcitonin levels. In order to differentiate whether only direct effects of elevated extracellular $\mathrm{Ca}^{2+}$ or the rise in plasma calcitonin were responsible for the inhibition of glucagon secretion under those circumstances we have infused calcitonin in 4 insulin-dependent diabetics: there was a substantial fall of both, blood glucose and plasma glucagon, whereas $\mathrm{Ca}^{2+}$ remained unchanged. Thus, we suggest that an increase of circulating calcitonin levels induced by $\mathrm{Ca}^{2+}$ infusions or by exogenous calcitonin administration appears to depress elevated circulating glucagon and glucose levels in insulin-dependent diabetics.
Acknowledgements. The authors are grateful to Mrs. I. Hansen and Mrs. M. Schütte for their skilled technical assistance. This study was supported by the Fonds of Deutsche Forschungsgemeinschaft (SFB 113, Diabetesforschung, project $\mathrm{H}$ 1).

\section{References}

1. Starke A, Keck E, Cüppers HJ, Zaremba A, Zimmermann H, Krüskemper HL (1980) The effect of $\mathrm{Ca}^{2+}$ on glucagon secretion stimulated by arginine and hypoglycaemia. In: Andreani D, Lefebvre PJ, Marks V (eds) Current views on hypoglycaemia and glucagon. Academic Press, London New York Toronto Sydney San Francisco, p 487-488

2. Valverde I, Dobbs RE, Unger RH (1975) Heterogeneity of plasma glucagon immunoreactivity in normal, depancreatized and alloxan diabetic dogs. Metabolism 24: 1021-1028

3. Valverde I, Villanueva ML (1976) Heterogeneity of plasma immunoreactive glucagon. Metabolism 25: 1393-1395

4. Jaspan JB, Rubenstein AH (1977) Circulating glucagon. Plasma profiles and metabolism in health and disease. Diabetes 26: 887-902

5. Unger RH, Orci L (1976) Physiology and pathophysiology of glucagon. Physiol Rev 55: 778-826

6. Bell NH, Queener S (1974) Stimulation of calcitonin synthesis and release in vitro by calcium and dibutyryl cyclic AMP. Nature 248: 343

7. Faloona GR, Unger RH (1974) Glucagon. In: Jaffe RB, Behrmann HR (eds) Methods of hormone radio immunoassay. Academic Press, New York London, p 317-330

8. Kemmer FW, Berchtold P, Berger M, Starke A, Cüppers HJ, Gries FA, Zimmermann H (1979) Exercise-induced fall of blood glucose in insulin-treated diabetics unrelated to alteration of insulin mobilization. Diabetes 28: 1131-1137

9. Dietrich FM, Hunziker WH, Fischer JA (1975) Synthetic human calcitonin: analysis of antibodies obtained from various animal species and determination of immunoreactive hormone in human sera. Acta Endocrinol (Kbh) 80: 465-486

10. Unger RH, Orci L (1975) Hypothesis: the essential role of glucagon in the pathogenesis of diabetes mellitus. Lancet I: $14-16$

11. Unger RH (1978) Role of glucagon in the pathogenesis of diabetes. The status of controversy. Metabolism 27: 1691-1709

12. Sakurai H, Dobbs RE, Unger RH (1975) The role of glucagon in the pathogenesis of the endogenous hyperglycaemia of diabetes mellitus. Metabolism 24: 1287-1297

13. Sakurai H, Dobbs RE, Unger RH (1974) Somatostatininduced changes in insulin and glucagon secretion in normal and diabetic dogs. J Clin Invest 54: 1395-1402

14. Schusdziara V, Rivier J, Dobbs RE, Brown M, Vale W, Unger RH (1978) Somatostatin analogs as glucagon suppressants in diabetes. Horm Metab Res 10: 563-565

15. Luyckx A, Lefebvre PJ (1980) Further studies in the role of prostaglandins in glucagon secretion. In: Andreani D, Lefebvre PJ, Marks V (eds) Current views on hypoglycaemia and glucagon. Academic Press, London New York Toronto Sydney San Francisco, p 47-56

16. Beveridge T, Niederer W, Nüsch E, Petrin A (1976) Pharmacokinetic study with synthetic salmon calcitonin. Z Gastroenterol 10: 12-15

17. Petralito A, Lunetta M, Liuzzo A, Fiore CF, Heynen G (1979) Effects of salmon calcitonin on blood glucose and insulin levels under basal conditions and after intravenous glucose load. $J$ Endocrinol lnvest 2: 209-211

18. Cantalamessa L, Catania A, Reschini E, Peracchi M (1978) 
Inhibitory effect of calcitonin on growth hormone and insulin secretion in man. Metabolism 27: 987-992

19. Ziegler R, Bellwinkel S, Schmidtchen D, Minne H (1972) Effects of hypercalcaemia, hypocalcaemia and calcitonin on glucose-stimulated insulin secretion in man. Horm Metab Res 4: 60

20. Sgambato S, Passariello N, Giugliano D, D'Onofrio F (1979) Effect of calcitonin on insulin-response to arginine in man. Diabete Metab. 5: 213-216

21. Ohneda A, Matsuda K, Horigome K, Ishii S, Yamagata S (1974) Effect of intrapancreatic administration of calcium upon glucagon secretion in dogs. Tohoku J Exp Med 113: 301-311

22. Tamarit J, Mayor P (1978) Effect of $\mathrm{Ca}^{2+}$ intravenous load on insulin and glucagon secretion. Diabetologia 15: 275

23. Rasmussen H (1971) Ionic and hormonal control of calcium homeostasis. Am J Med 50: 567-584

24. Rasmussen H, Bordier P, Kurokawa K, Nagata N, Ogata E (1974) Hormonal control of skeletal and mineral homeostasis. Am J Med 56: 751-758

25. Borle AB (1975) Regulation of the mitochondrial control of cellular calcium homeostasis and calcium transport by phosphate, parathyroid hormone, calcitonin, vitamin $\mathrm{D}$, and cyclic AMP - Calcium regulatory hormones. Excerpta Medica, Amsterdam, p 217

26. Copp H (1974) Accion de la calcitonina. Metabolismo del calcio. Oteo Ed, Madrid, p 23

27. Leclercq-Meyer V, Marchand J, Malaisse WJ (1973) The effect of calcium and magnesium on glucagon secretion. Endocrinology 93: 1360-1370
28. Leclercq-Meyer V, Marchand J, Malaisse WJ (1976) The role of calcium in glucagon release, interactions between glucose and calcium. Diabetologia 12: 531-538

29. Tamarit-Rodriguez J, Cebeira M, Tamarit J, Garcia C, Roncero J (1978) Calcitonin modulation of insulin and glucagon release by the isolated and perfused rat pancreas. Diabetologia 15: 275

30. Hermansen K, Iversen I (1976) Calcium, glucose and glucagon release. Diabetologia 12: 398

31. Lundquist I, Fanska R, Grodsky GM (1976) Interaction of calcium and glucose on glucagon secretion. Endocrinology 99 : 1304-1312

32. Malaisse WJ, Herchuelz A, Levy J, Sener A (1977) Calcium antagonists and islet function. III. The possible site of action of verapamil. Biochem Pharmacol 26: 735-740

33. Leclercq-Meyer V, Marchand J, Malaisse WJ (1978) The role of calcium in glucagon release. Studies with verapamil. Diabetes 27: 996-1004

Received: 7 July 1980 , and in revised form: 4 December 1980

Dr. A. Starke

Medizinische Klinik E der Universität

Moorenstraße 5

D-4000 Düsseldorf 1

Federal Republic of Germany 